\title{
Cell-cycle-phase progression analysis identifies unique phenotypes of major prognostic and predictive significance in breast cancer
}

\author{
M Loddo ${ }^{1,6}$, SR Kingsbury ${ }^{2,6}$, M Rashid', I Proctor' ${ }^{\prime}$, C Holt $^{3}$, J Young ${ }^{3}$, S El-Sheikh', M Falzon', KL Eward ${ }^{3}$, \\ T Prevost ${ }^{1,4}$, R Sainsbury ${ }^{5}$, K Stoeber ${ }^{*, 1,2,7}$ and GH Williams ${ }^{1,2,7}$
}

'Department of Pathology and Cancer Institute, The Paul O'Gorman Building, University College London, Gower Street, London WCIE 6BT, UK; ${ }^{2}$ Wolfson Institute for Biomedical Research, University College London, The Cruciform Building, Gower Street, London WCIE 6BT, UK; ${ }^{3}$ Department of Life Sciences, Faculty of Science and Technology, Anglia Ruskin University, East Road, Cambridge CBII IPT, UK; ${ }^{4}$ Department of Public Health and Primary Care, Centre for Applied Medical Statistics, University of Cambridge, Institute of Public Health, Forvie Site, Robinson Way, Cambridge CB2 OSR, UK; ${ }^{5}$ Department of Breast Surgery, Princess Ann Hospital, Southampton SO 16 YYA, UK

\begin{abstract}
Multiparameter analysis of core regulatory proteins involved in $\mathrm{G}$ I-S and $\mathrm{G} 2-\mathrm{M}$ cell-cycle transitions provides a powerful biomarker readout for assessment of the cell-cycle state. We have applied this algorithm to breast cancer to investigate how the cell cycle impacts on disease progression. Protein expression profiles of key constituents of the DNA replication licensing pathway (Mcm2, geminin) and mitotic machinery (PIkI, Aurora A and the Aurora substrate histone H3SIOph) were generated for a cohort of I82 patients and linked to clinicopathological parameters. Arrested differentiation and genomic instability were associated with an increased engagement of cells into the cell division cycle $(P<0.000 I)$. Three unique cell-cycle phenotypes were identified: $(I)$ welldifferentiated tumours composed predominantly of $\mathrm{Mcm} 2$-negative cells, indicative of an out-of-cycle state (I 8\% of cases); (2) high Mcm2-expressing tumours but with low geminin, Aurora A, PlkI and H3SIOph levels (S-G2-M progression markers), indicative of a Gl-delayed/arrested state (24\% cases); and (3) high Mcm2-expressing tumours and also expressing high levels of the S-G2-M progression markers, indicative of accelerated cell-cycle progression (58\% of cases). The active cell-cycle progression phenotype had a higher risk of relapse when compared with out-of-cycle and $\mathrm{Gl}$-delayed/arrested phenotypes $(\mathrm{HR}=3.90(\mathrm{I} .8 \mathrm{I}-8.40, P<0.00 \mathrm{I}))$, and was associated with Her-2 and triple negative subtypes $(P<0.00 \mathrm{I})$. It is of note that high-grade tumours with the GI-delayed/ arrested phenotype showed an identical low risk of relapse compared with well-differentiated out-of-cycle tumours $(\mathrm{HR}=1.00$ $(0.22-4.46), P=0.99)$. Our biomarker algorithm provides novel insights into the cell-cycle state of dynamic tumour cell populations in vivo. This information is of major prognostic significance and may impact on individualised therapeutic decisions. Patients with an accelerated phenotype are more likely to derive benefit from S- and M-phase-directed chemotherapeutic agents.

British Journal of Cancer (2009) I 00,959-970. doi:I0.1038/sj.bjc.6604924 www.bjcancer.com

Published online 24 February 2009

(c) 2009 Cancer Research UK
\end{abstract}

Keywords: Aurora A; DNA replication licensing; aneuploidy; prognosis; breast cancer; predictive testing

Cancer is a heterogeneous and complex group of diseases caused by the accumulation of genetic lesions, which increase the activity of regulatory genes that drive cell proliferation and decrease the activity of proteins that normally inhibit it. Activation of dominant stimulatory oncogenes or inactivation of recessive tumour suppressor genes can affect all levels of growth-signalling pathways, including mitogens, mitogen growth factor receptors PI3kinase-Akt, Ras, Raf and ABL, upstream of molecules such as p16INK4A, Cyclin D, Myc, Cyclin E, p53, and downstream of $\mathrm{pRB}$. Global gene expression profiling is ideally suited for analysis

* Correspondence: Dr K Stoeber, Wolfson Institute for Biomedical Research, University College London, The Cruciform Building, Gower Street, London WCIE 6BT, UK; E-mail: k.stoeber@ucl.ac.uk

${ }^{6}$ These authors contributed equally to this work

${ }^{7}$ These authors are supported by the EU Sixth Framework Programme Integrated Project 'MitoCheck'

Received 24 September 2008; revised 19 December 2008; accepted 12 January 2009; published online 24 February 2009 of the complex multifactorial, interactive and stepwise alterations in gene expressions that characterise tumorigenesis (Perou et al, 1999; Ross et al, 2000). The analysis of complex and redundant pathways that control proliferation, differentiation, apoptosis and DNA damage response by global genome-wide analysis is an intensive area of investigation aimed at identifying unique molecular signatures and biomarkers of prognostic and predictive significance in cancer (Van 't Veer et al, 2002; Paik et al, 2004). However, the actual performance of prediction rules using gene expression profiling has not turned out to be as informative as initially expected for many tumour types, and the list of genes identified can be highly unstable (Michiels et al, 2005; Dunkler et al, 2007). An alternative approach is to focus directly on the cellcycle machinery, which acts as an integration point for information transduced through upstream pathways (Stoeber et al, 2001; Gonzalez et al, 2005; Williams and Stoeber, 2007).

The cell cycle represents a highly regulated series of events that leads to eukaryotic cell reproduction. Early in the cycle, the DNA is replicated and the chromosomes are duplicated during transit through $S$ phase. This process begins at specific DNA sites called 
replication origins. At these sites, the DNA replication licensing machinery opens the DNA double helix, exposing it to the enzymes that carry out DNA synthesis (Machida et al, 2005). S phase is followed by chromosomal segregation, nuclear division and cell division, which is collectively called $M$ phase. Most cell cycles contain additional gap phases between $S$ and $M$ phases, which provide additional time for growth and also serve as important regulatory transitions, through which progression to the next cellcycle stage can be controlled by intracellular and extracellular signals (Nigg, 2001; Sherr and Roberts, 2004) (Figure 1A). G1 is a particularly important regulatory period, because it is here that most cells become committed to either continued division or exit from the cell cycle (Zetterberg and Larsson, 1985; Planas-Silva and Weinberg, 1997). In the presence of unfavourable conditions or inhibitory signals, cells can normally withdraw from the cell cycle into quiescent (G0), terminally differentiated or senescent out-ofcycle states, a characteristic feature of most of the functionally differentiated cells of the human body (Stoeber et al, 2001; Blow and Hodgson, 2002). Cancers, in contrast, are characterised by uncontrolled cell growth and, therefore, contain a high proportion of cycling cells. It is for this reason that many of the chemotherapeutic agents and newly emerging small-molecule inhibitors are cell-cycle-phase-specific.

The DNA replication licensing machinery represents a complex of initiator proteins, which bind and open the DNA at origins establishing replication forks. During late mitosis and early G1 phases, there is a sequential assembly of the replication licensing factors, ORC, Cdc6, Cdt1 and Mcm2-7, at replication origins to form pre-replicative complexes, rendering origins 'licensed' for DNA synthesis during $S$ phase. At the G1-S transition, cyclindependent kinases and the ASK-dependent Cdc7 kinase trigger a conformational change in the pre-replicative complex, referred to as 'origin firing', resulting in the recruitment of Cdc45, Mcm10 and additional initiator proteins, which collectively promote origin unwinding and the recruitment of DNA polymerases (Machida et al, 2005). Expression of the licensing repressor, geminin, during $\mathrm{S}-\mathrm{G} 2-\mathrm{M}$ phases prevents inappropriate re-initiation events through its interaction with Cdt1, resulting in a block to Mcm2 - 7 loading to chromatin (Hook et al, 2007). We and others have shown that the $\mathrm{Mcm} 2-7$ replication licensing factors, constituents of the heterohexameric DNA replicative helicase, are expressed throughout all cell-cycle phases (G1-S-G2-M), but are tightly downregulated during exit into out-of-cycle states (Stoeber et al, 2001; Barkley et al, 2007; Williams and Stoeber, 2007). The repression of origin licensing contributes to replication arrest and loss of proliferative capacity, as cells exit the mitotic cycle into the out-of-cycle state (Blow and Hodgson, 2002). This allows a functional distinction between the proliferative state and the non-proliferative out-of-cycle state, depending on whether origins are licensed (Blow and Hodgson, 2002). Detection of $\mathrm{Mcm} 2-7$ is therefore a powerful way of assessing the proliferative potential of the cell. We and others have shown that these unique biomarkers can clearly distinguish between cycling cells and the out-of-cycle state in a range of tissue types, including premalignant and malignant disorders (Freeman et al, 1999; Gonzalez et al, 2005; Williams and Stoeber, 2007). As neoplastic cells are characterised by uncontrolled proliferation, $\mathrm{Mcm}$ expression is currently being exploited as a cancer diagnostic marker in a broad range of tumour types (Gonzalez et al, 2005; Tachibana et al, 2005; Williams and Stoeber, 2007).

The rigorous control of mitotic events (M phase) is essential for successful completion of sister-chromatid segregation and cell division. Although cyclin-dependent kinases are the master regulators of mitotic entry, they do not act alone. Polo-like kinase 1 (Plk1), Aurora A and Aurora B are three additional protein kinases that control a subset of critical mitotic events, including centrosome maturation and separation, chromosome orientation and segregation (Nigg, 2001). These mitotic kinases are currently
A

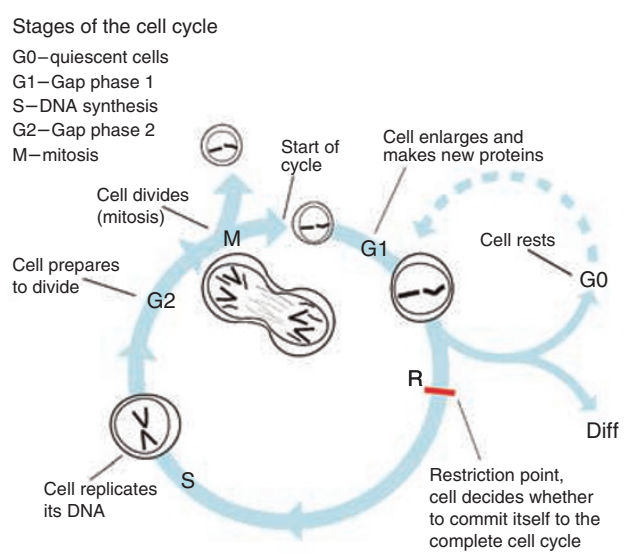

B

\begin{tabular}{|c|c|c|c|c|c|}
\hline & \multicolumn{4}{|c|}{ Proliferating cells } & $\begin{array}{l}\text { Out of cycle } \\
\text { states }\end{array}$ \\
\hline & G1 & $\mathrm{s}$ & G2 & M & Go/Diff \\
\hline Mcm2-7 & + & + & + & + & - \\
\hline Geminin & - & + & + & + & - \\
\hline Aurora $\mathrm{A}$ & - & + & + & + & - \\
\hline Plk1 & - & + & + & + & - \\
\hline H3S10ph & - & - & - & + & - \\
\hline
\end{tabular}

\section{C}

\begin{tabular}{|c|c|c|c|}
\hline Drug & Target & Mechanism of action & $\begin{array}{l}\text { Phase } \\
\text { affected }\end{array}$ \\
\hline 5-fluorouracil & Thymidalate synthetase & Ribonucleotide depletion & $\mathrm{s}$ \\
\hline Hydroxyurea & $\begin{array}{l}\text { Ribonucleotide } \\
\text { reductase }\end{array}$ & Ribonucleotide depletion & $\mathrm{s}$ \\
\hline Methotrexate & Dihydrofolate reductase & Ribonucleotide depletion & $\mathrm{S}$ \\
\hline Epirub icin & Topoisomerase II & $\begin{array}{l}\text { Stabilisation of Topoisomerase II- } \\
\text { DNA complex, which leads to } \\
\text { replication arrest }\end{array}$ & s \\
\hline Etoposide & Topoisomerase II & $\begin{array}{l}\text { Stabilisation of Topoisomerase II- } \\
\text { DNA complex, which leads to } \\
\text { replication arrest and strand } \\
\text { breakage }\end{array}$ & $\mathrm{S}$ or G2/M \\
\hline Cisplatin & DNA & $\begin{array}{l}\text { Intra-strand crosslinking, which } \\
\text { leads to replication arrest }\end{array}$ & $\begin{array}{l}\text { G1/S and } \\
\text { G2/M }\end{array}$ \\
\hline Docetaxel & Tubulin & Stabilisation of microtubules & M \\
\hline Flavopiridol & $\begin{array}{l}\text { CDK1, CDK2, CDK4, } \\
\text { CDK6 and CDK7 }\end{array}$ & $\begin{array}{l}\text { Inhibition of CDKs by interfering } \\
\text { with ATP binding }\end{array}$ & Several \\
\hline Staurosporine & CDK1 & $\begin{array}{l}\text { Inappropriate activation of CDK1 } \\
\text { by phosphorylation }\end{array}$ & $\begin{array}{c}\mathrm{G} 2 / \mathrm{M} \\
\text { abrogated }\end{array}$ \\
\hline ZM447439 & Aurora kinase $\mathrm{A}$ and $\mathrm{B}$ & $\begin{array}{l}\text { Inhibit s histone } \mathrm{H} 3 \\
\text { phosphorylation on serine } 10\end{array}$ & G2/M \\
\hline BI 2536 & Polo-like kinase 1 & $\begin{array}{l}\text { Arrests cells in prometaphase and } \\
\text { initiates cyclin A destruction }\end{array}$ & M \\
\hline
\end{tabular}

Figure I (A) Diagrammatic representation of the mitotic cell division cycle. (B) Phase-specific distribution of cell-cycle biomarkers in proliferating cells and out-of-cycle states. (C) Cell-cycle-phase-specific chemotherapeutic and mechanistic agents. Drugs highlighted in green are commonly used in the treatment of breast cancer. 
the focus of major clinical interest, as small-molecule inhibitors targeting these enzymes have potent tumour-killing effects (Keen and Taylor, 2004; Plyte and Musacchio, 2007). We have shown earlier in human cells and tissues that, similar to geminin, endogenous levels of Aurora A/B and Plk1 are tightly regulated in a cell-cycle-dependent manner, which is undetectable in G1 phase, accumulates during $S$ phase and reaches a peak in G2/M phase, followed by a rapid degradation at the end of mitosis (Kulkarni et al, 2007). Histone $\mathrm{H} 3$ is a substrate for the Aurora kinases and is phosphorylated on Serine 10 only in mitosis (Crosio et al, 2002). Therefore, geminin, Aurora A/B and Plk1 represent biomarkers of the $\mathrm{S}-\mathrm{G} 2-\mathrm{M}$ progression, whereas phosphohistone (H3S10ph) represents a biomarker of the M-phase transition (Gurley et al, 1978; Paulson and Taylor, 1982; Wei et al, 1999; Crosio et al, 2002; Wohlschlegel et al, 2002; Kulkarni et al, 2007; Williams and Stoeber, 2007) (Figure 1B).

Multiparameter analysis of $\mathrm{Mcm} 2-7$, geminin, Aurora A, Plk1 and H3S10ph, core regulators of the G1-S and G2-M transitions, thus allows a detailed analysis of the kinetics of complex dynamic tumour cell populations. This biomarker set not only allows the out-of-cycle state to be distinguished from G1 but also provides an assessment of cell-cycle progression and cell-cycle-phase distribution (Williams and Stoeber, 2007) (Figure 1B). These proteins are readily detectable immohistochemically in surgical biopsy tumour samples and can, therefore, be used to determine the cell-cycle dynamics of individual patient samples. Interestingly, the proliferation signature, which includes cell-cycle regulatory proteins, has emerged as one of the most prominent prognostic gene-expression patterns in genome-wide analysis studies (Whitfield et al, 2006). Here we therefore set out to test the hypothesis whether a tumour's cell-cycle phenotype might also provide information regarding in vivo behaviour and disease progression, and whether the cell-cycle-phase distribution analysis might also provide a guide for selection of patients most likely to benefit from cell-cycle-phase-specific chemotherapeutic agents (Figure 1C).

Breast cancer was selected as the tumour model system of choice to test this novel cell-cycle algorithm because current prognostic and predictive tools for this common malignancy have limited discriminant utility, and adjuvant chemotherapy for this particular tumour type utilises cell-cycle-phase-specific agents (Michiels et al, 2005, 2007; Dunkler et al, 2007). The best prognostic tool described to date for identifying which patients are most likely to benefit from adjuvant chemotherapy is the Nottingham Prognostic Index (NPI), which includes morphological correlates of biological features of aggressive disease (Elston and Ellis, 1991). This includes tumour size, lymph node spread and grade. The latter is a combined index of differentiation status, nuclear pleomorphism reflecting genomic instability and number of cells in M phase (Elston and Ellis, 1991; Rampaul et al, 2001). Patients can be divided into good (NPI score $<3.4 ; 15$-year survival rate $80 \%$ ), moderate (NPI score: $3.4-5.4$; 15-year survival rate: $42 \%$ ) and poor (NPI score: $>5.4$; 15 -year survival rate: $13 \%$ ) prognostic groups, on which therapeutic decisions can be based (Elston and Ellis, 1991). However, up to one-third of women with negative axillary lymph nodes will suffer recurrence, whereas approximately one-third of node-positive patients not receiving adjuvant therapy remain recurrence-free after 10 years (EBCTCG, 1998a,b). We have conducted an analysis of the $\mathrm{G} 1-\mathrm{S}$ and $\mathrm{G} 2-\mathrm{M}$ regulators to determine the relationship between cell-cycle state, tumour differentiation status and the acquisition of genomic instability in breast cancer, and how this cell-cycle phenotype might impact on in vivo behaviour. We have also investigated whether the cell-cycle phenotype provides additional prognostic information independent of the gold standard NPI, and how this might influence the selection of patients for neoadjuvant or adjuvant cell-cycle-phase-specific therapy (Figure 1C).

\section{MATERIALS AND METHODS}

\section{Study cohort}

A total of 182 patients diagnosed with invasive breast cancer between 1999 and 2004 were identified from the Breast Cancer Database held in the Department of Surgery at University College London (UCL) Hospitals (London, UK). Patients were selected on the basis of available histological material. Histological specimen had been reviewed by a qualified breast pathologist at diagnosis and assessed for histological subtype and nuclear grade according to the World Health Organization (WHO) criteria. All patients studied underwent a regular postoperative clinical assessment and contributed to the cross-sectional analyses. Ten patients were lost to follow-up, but five were known to have had recurrent cancer, of whom two died. A total of 167 patients contributed to the prospective analyses of survival and relapse, of whom 24 (14\%) died from cancer within the study period, 12 died from other unrelated causes and 131 were still alive at last follow-up. There were $40(24 \%)$ relapse events comprising relapses and deaths from cancer. The median follow-up period was 47 months (range: 1 -92). The mean time to relapse was 26 months (s.d. $=15$, range: 2 -55). The mean follow-up time among those who had not yet relapsed was 52 months (s.d. $=20$, range: $2-92$ ). The mean survival time among those who died was 21 months (s.d. $=12$, range: $4-44)$. The mean follow-up time among those still alive was 50 months (s.d. $=21$, range: $1-92$ ).

Formalin-fixed, paraffin-embedded breast tissues from these patients were retrieved from the archives of the Department of Pathology (UCL Hospitals, London, UK), and included all three histological grades $(1-3)$ calculated according to the Nottingham modification of the Bloom and Richardson method (Elston and Ellis, 1991). Histological reports and specimens were available for all cases. These included 142 invasive ductal carcinomas, 26 lobular, 4 mucinous, 1 micropapillary and 9 of mixed type. Breast cancers were also subdivided on the basis of their hormone receptor status, Her-2 expression and basal cytokeratin (CK 5) expression. Using this immunohistochemistry-based approach, cancers were subdivided into three groups: (1) $\mathrm{ER} / \mathrm{PR}+$, Her-2 + I- $(n=145)$; (2) ER/PR - , Her-2 + $(n=11)$; and (3) ER/PR - , Her-2- $(n=26)$. These subgroups are clinically relevant and also approximate to the 'luminal', 'Her-2' and 'triple negative/basal-like' breast cancer subtypes, earlier defined by microarray-based gene expression profiling (Sorlie et al, 2001). Parameters recorded include date of birth, histological grade, tumour size, tumour type, lymph node status, lymphovascular invasion (LVI), date of diagnosis, date of relapse, date of last follow-up, and date and cause of death. The NPI was calculated according to the following formula: NPI score $=0.2 \times$ tumour size + tumour grade + nodal status (Rampaul et al, 2001). Randomly selected cases of normal breast tissue from 21 premenopausal women who had undergone reduction mammoplasty were additionally included in the study. Local research ethics committee approval for the study was obtained from the joint UCL/UCLH Committees on the Ethics of Human Research.

\section{Antibodies}

A rabbit polyclonal antibody against human geminin was generated as described (Wharton et al, 2004). Ki67 monoclonal antibody (MAb) (clone MIB-1) was obtained from DAKO (Glostrup, Denmark), Mcm2 MAb (clone 46) from BD Transduction Laboratories (Lexington, KY, USA), oestrogen receptor- $\alpha$ (ER) $\mathrm{MAb}$ (clone 1D5) and progesterone receptor (PR) MAb (clone PgR 636) from DAKO, Aurora A MAb NCL-L-AK2 (clone JLM28) from Novocastra Laboratories (Newcastle, UK), Plk1 MAb (clone 35-206) and Histone $\mathrm{H} 3$ phosphorylated on Serine 10 (H3S10ph) polyclonal antibody from Upstate (Lake Placid, NY, USA). 


\section{Cell culture and synchronisation}

Human MCF-7 breast epithelial adenocarcinoma cells (HTB-22; ATCC, Teddington, UK) were cultured in EMEM (Gibco-BRL, Invitrogen, Carlsbad, CA, USA) supplemented with $2 \mathrm{~mm}$ glutamine, $1 \%$ non-essential amino acids, $10 \%$ FCS, $100 \mathrm{U} \mathrm{ml}^{-1}$ penicillin and $0.1 \mathrm{mg} \mathrm{ml}^{-1}$ streptomycin.

\section{Preparation of protein extracts and immunoblotting}

MCF-7 cells were harvested by treatment with trypsin, washed in PBS and resuspended in lysis buffer $(50 \mathrm{~mm}$ Tris-Cl, $\mathrm{pH} 7.5$, $150 \mathrm{~mm} \mathrm{NaCl}, 20 \mathrm{~mm}$ EDTA, $0.5 \% \mathrm{NP}-40$ ) at $2 \times 10^{7}$ cells $/ \mathrm{ml}$. After incubation on ice for $30 \mathrm{~min}$, the lysate was clarified by centrifugation $\left(13000 \mathrm{~g}, 15 \mathrm{~min}, 4^{\circ} \mathrm{C}\right)$. Lysates were separated by $4-20 \%$ SDS - PAGE (75 $\mu \mathrm{g}$ protein/well) and immunoblotted as described (Stoeber et al, 2001). Blocking, antibody incubations and washing steps were performed using the following conditions: PBS/ $0.1 \%$ Tween-20/5\% milk for Mcm2, Aurora A and Plk1; PBS/1\% Tween-20/10\% milk for geminin; and PBS/5\% milk for H3S10ph.

\section{Immunohistochemistry}

Archival formalin-fixed, paraffin-embedded tissue (PWET) obtained at initial diagnosis was available for all patients, and for each specimen, a block was chosen that contained a representative sample of invasive tumour. Consecutive serial sections cut from each PWET block were used for immunohistochemistry. Sections of 3- $\mu \mathrm{m}$ thickness were cut onto Superfrost Plus slides (Visions Biosystems, Newcastle Upon Tyne, UK), dewaxed in xylene and rehydrated through graded alcohol to water. The tissue sections were pressure-cooked in $0.1 \mathrm{M}$ citrate buffer at $\mathrm{pH} 6.0$ for $2 \mathrm{~min}$ and immunostained using the Bond $^{\mathrm{TM}}$ Polymer Refine Detection kit and Bond ${ }^{\mathrm{TM}}$-Max automated system (Vision Biosystems). Primary antibodies were applied at the following dilutions: Ki67 (1:300), Mcm2 $(1: 2000)$, geminin $(1: 600)$, ER $(1: 200)$, PR $(1: 200)$, Aurora A $(1: 70)$, Plk1 $(1: 1000)$ and H3S10ph $(1: 300)$. Her-2 immunostaining was performed using the DAKO HercepTest $^{\mathrm{TM}}$ (DAKO), according to the manufacturer's instructions. Coverslips were applied with Pertex mounting medium (CellPath Ltd, Newtown, Powys, UK). Incubation without a primary antibody was used as a negative control and colonic epithelial sections as positive controls.

\section{Protein expression profile analysis}

Protein expression analysis was performed by determining the labelling index (LI) of the markers in each tumour as described (Dudderidge et al, 2005; Shetty et al, 2005; Kulkarni et al, 2007). Slides were evaluated at low-power magnification $(\times 100)$ to identify the regions of tumour with the highest intensity of staining. From these selected areas, 3-5 fields at $\times 400$ magnification were captured with a charged-coupled-device camera and analysis software (SIS, Münster, Germany). Images were subsequently printed for quantitative analysis, which was performed with the observer unaware of clinicopathological variables. Both positive and negative cells within the field were counted and any stromal or inflammatory cells were excluded. Criteria for identification of positive cells were dependent on the biomarker: for Ki67, Mcm2, geminin and H3S10ph, cells with any degree of nuclear staining were scored positive; for Aurora A and Plk1, cells with any degree of nuclear or cytoplasmic staining were scored positive. A minimum total of 500 cells were counted for each case. The LI was calculated using the following formula: $\mathrm{LI}=$ number of positive cells/total number of cells $\times 100$ as described (Kulkarni et al, 2007). To evaluate ER and PR expressions, the quick (Allred) score system was used and positivity was defined as a quick score of $>3$ as described earlier
(Harvey et al, 1999; Gown, 2008). Her-2 protein overexpression was assessed using the Food and Drug Administration (FDA)approved scoring system recommended by DAKO. The reassessment of 10 randomly selected cases by an independent assessor showed high levels of concordance.

\section{DNA image cytometry}

For each case, one $40 \mu \mathrm{m}$ section of PWET, obtained from the same block as that assessed by immunohistochemistry, was used to prepare nuclei as described (Haroske et al, 1998). The Fairfield DNA Ploidy System (Fairfield Imaging Ltd, Nottingham, UK) was used for image processing, analysis and classification as described (Haroske et al, 1998). Lymphocytes and plasma cells were included as internal controls and $40 \mu \mathrm{m}$ sections of high-grade bladder tumour and normal colonic tissue as external controls for aneuploid and diploid populations, respectively. Histograms were classified according to the published criteria (Haroske et al, 1998) by two independent assessors with a high level of agreement without the knowledge of clinicopathological variables. For statistical analysis, tetraploid and polyploid tumours were grouped together with aneuploid tumours.

\section{Statistical analysis}

Biomarker labelling indices were summarised with the median and interquartile range. The Mann-Whitney $U$-test was used to compare each marker with lymph node stage, ploidy status and with grade 3 against the normal sample. The Jonckheere-Terpstra non-parametric test for trend was used to compare markers across grade and Her-2 status. Spearman's rank correlation coefficient was used to assess associations between markers and NPI. The $\chi^{2}$-test for a linear-by-linear association with 1 d.f. was used to test for association between Her-2 and ploidy status. The unpaired $t$-test was used to compare mean NPI according to the ploidy status. Linear regression was used to assess for trend in mean NPI across Her-2. Cox regression was used in the analysis of disease-free survival and overall survival to provide hazard ratios and to assess the prediction of markers, split into two categories at the median, both in univariate models and in multivariate models adjusting for NPI. Kaplan-Meier plots were used to show the estimated predictive effects of markers ignoring, and also stratified by, the NPI category. Relationships between cell-cycle phenotype and clinical parameters were assessed using Pearson's $\chi^{2}$-test for grade, positive nodes and Her-2 status; using one-way analysis of variance for age, size and NPI; and using the Jonckheere-Terpstra test for ER and PR. All tests were two-sided, with effects summarised using 95\% confidence intervals and assessed as statistically significant at the 5\% level using SPSS software (version 15.0, SPSS Inc., Chicago, IL, USA).

\section{RESULTS}

\section{Cell-cycle-phase progression analysis of normal and malignant breast tissues}

Monospecificity of antibodies against $\mathrm{Mcm} 2$, geminin, Plk1, Aurora A and the Aurora kinase substrate H3S10ph was confirmed in total cell extracts from asynchronous MCF-7 breast cancer cells by detection of a single protein with a molecular mass consistent with the reported electrophoretic mobility of the corresponding human antigen (Supplementary Figure 1A). Next, we studied the expression of these $\mathrm{G} 1-\mathrm{S}$ and $\mathrm{G} 2-\mathrm{M}$ regulators in normal breast specimens after reduction mammoplasty and in poorly differentiated, aggressive high-grade (grade 3 ) tumours. High levels of $\mathrm{Mcm} 2$ protein were detected in epithelial cells of the terminal duct lobular unit (TDLU), indicating that these cells reside in an incycle state (median: $33.5 \%$ ) and not in G0 state (Stoeber et al, 2001; Blow and Hodgson, 2002; Gonzalez et al, 2005; Williams and 
Stoeber, 2007). However, whereas $\mathrm{Mcm} 2$ levels were high, Ki67 was expressed at low levels (median: $2.8 \%$ ). It is of note that geminin, Aurora A, Plk1 (S-G2-M-phase makers) and H3S10ph (M-phase marker) were only expressed in a very small fraction of cells $(<1 \%)$ of the TDLU, indicating a block to cell-cycle progression (Supplementary Figure 1B). This cell-cycle phenotype is in keeping with a G1-delayed/arrested state as reported earlier (Stoeber et al, 2001; Gonzalez et al, 2004; Shetty et al, 2005; Williams and Stoeber, 2007). A higher proportion of tumour cells expressed the Mcm2 licensing factor when compared with the normal mammary epithelium, indicating a greater number of cells engaged in a cell cycle (median values: $\mathrm{Mcm} 2: 92.3$ vs 33.5\%, $P<0.001$ ). However, in contrast to normal breast tissue, high-level $\mathrm{Mcm} 2$ expression was also coupled to a high-level expression of the S-G2-M markers, geminin, Aurora A, Plk1, and the mitotic marker, H3S10ph, in breast cancer (median values: geminin $(0.98$ vs $17.4 \%, P<0.001)$, Aurora A (0 vs 11.7\%, $P<0.001)$, Plk1 (0.37 vs $14.2 \%, P<0.001)$ and $\mathrm{H} 3 \mathrm{~S} 10 \mathrm{ph}(0$ vs $2.5 \%, P<0.001))$, a phenotype indicative of active cell-cycle progression (Wohlschlegel et al, 2002; Gonzalez et al, 2004; Wharton et al, 2004; Dudderidge et al, 2005; Obermann et al, 2005; Kulkarni et al, 2007; Williams and Stoeber, 2007) (Supplementary Figure 1B). Although Ki67 levels were low in the G1-arrested or-delayed state, characterising the normal mammary epithelium, high levels of Ki67 were associated with the actively cycling tumour phenotype (Ki67: 2.8 vs 40.2\%, $P<0.001$ ).

\section{Relationship between cell-cycle state, tumour differentiation status, genomic instability and metastasis}

Cell-cycle state and tumour differentiation The clinicopathological characteristics of the study cohort are summarised in Supplementary Table 1, which includes grade and associated receptor status. First, we examined the relationship between expressions of the $\mathrm{G} 1-\mathrm{S}$ and $\mathrm{G} 2-\mathrm{M}$ regulators, and tumour grade. Expression levels of Mcm2, geminin, Plk1, Aurora A and H3S10ph were strongly associated with tumour grade (Supplementary Table 2). Arrested tumour differentiation was linked to the loss of ER and PR hormone receptor expressions and an increase in the expressions of $\mathrm{G} 1-\mathrm{S}$ and $\mathrm{G} 2-\mathrm{M}$ regulators. This indicates that increasing grade is coupled to an increase in the proportion of tumour cells engaged in the cell division cycle. This is in keeping with our observations in the HL60 differentiation model system that engagement of the somatic differentiation programme in tumour cells is coupled to G1 arrest and cell-cycle withdrawal into the out-of-cycle state, a process that is linked to repression of the DNA replication licensing machinery (Barkley et al, 2007). Interestingly, there was a significant overlap in the distribution of these cell-cycle proteins between grades (e.g., Aurora A and Plk1 levels, Supplementary Figure 2), which has important implications for exploitation of these molecules as predictors of therapeutic response to cell-cycle-phase-specific mechanistic agents (see Discussion). Expression levels of Ki67, $\mathrm{Mcm} 2$, geminin, Aurora A, Plk1 and H3S10ph showed a strong positive correlation, and those of ER and PR a negative correlation, with increasing NPI score, consistent with their link to differentiation status (Supplementary Table 3). Surprisingly, Her-2 expression did not show linkage to any of the G1-S or G2-M cell-cycle regulators, despite these factors acting downstream of mitogenic growth-signalling pathways, but there was a strong inverse association with PR expression $(P<0.001)$ (Supplementary Table 4$)$ and with increasing NPI score (Supplementary Table 5).

Cell-cycle state and genomic instability A highly significant association between tumour grade and genomic instability (ploidy status) was observed $(P<0.001)$. To investigate the relationship between $\mathrm{G} 1-\mathrm{S}$ and $\mathrm{G} 2-\mathrm{M}$ regulators and genomic instability, we linked their expression profiles to tumour DNA content (Supplementary Table 6). There was a highly significant association between the expression levels of all six cell-cycle biomarkers including Ki67 and aneuploidy (Ki67: $P<0.001, \mathrm{Mcm} 2: P=0.009$, geminin: $P<0.001$, Aurora A: $P<0.001$, Plk1: $P=0.002$ and H3S10ph: $P<0.001)$. This indicates an increased engagement of tumour cells in the cell division cycle for malignancies exhibiting genomic instability, when compared with diploid tumours (Kulkarni et al, 2007; Williams and Stoeber, 2007). A weak association was observed between aneuploidy and increasing Her2 expression $\left(\chi^{2}=3.03, P=0.08\right)$, and between aneuploidy and increasing NPI score (Supplementary Table 5).

Cell-cycle state and loco-regional metastasis No significant association was found between $\mathrm{Ki} 67, \mathrm{Mcm} 2$, geminin, Aurora A or Plk1 expressions and lymph node metastasis, but a weak association with the H3S10ph expression was observed $(P=0.02)$ (Supplementary Table 7). There was a strong inverse association with ER $(P=0.007)$ and PR $(P=0.005)$ expressions and lymph node metastasis.

\section{Relationship between cell-cycle state, tumour DNA ploidy status and patient outcome}

Univariate analysis In our patient cohort, the NPI score was a strong predictor of disease-free survival and overall survival, with the hazard of relapse increasing just below two-fold per unit of NPI score $(\mathrm{HR}=1.81 \quad(1.47-2.23), \quad P<0.001)$, and the hazard of dying increasing just above two-fold per unit of NPI score $(\mathrm{HR}=2.15$ (1.61-2.88), $P<0.001$ ) (Supplementary Table 8, Figure 2A). Patient's age was not a predictive factor. Ki67, Mcm2, geminin, Aurora A, Plk1 and $\mathrm{H} 3 \mathrm{~S} 10 \mathrm{ph}$ expressions were identified as strong predictors of disease-free survival $(\mathrm{HR}=2.77(1.44-5.30), P=0.002 ; \mathrm{HR}=3.00$ (1.56-5.76), $P<0.001 ; \mathrm{HR}=3.93(1.98-7.80), P<0.001 ; \mathrm{HR}=3.31$ (1.67-6.57), $P<0.001 ; \mathrm{HR}=4.48$ (2.21-9.09), $P<0.001$; and $\mathrm{HR}=3.49$ (1.76-6.92), $P<0.001$, respectively) (Figures $2 \mathrm{~B}$ and $\mathrm{C}$ and 3 ). The corresponding associations with overall survival were also appreciable, but generally smaller and not statistically significant, reflecting the smaller number of these events $(\mathrm{Mcm} 2$ : $\mathrm{HR}=2.32 \quad(0.99-5.43), P=0.05$; geminin: $\mathrm{HR}=2.43 \quad(1.04-5.68)$, $P=0.04$; Aurora A: $\mathrm{HR}=2.18(0.93-5.12), P=0.07 ; \mathrm{Plk} 1: \mathrm{HR}=3.46$ (1.37-8.71), $P=0.009$; H3S10ph: HR=3.29 (1.31-8.30), $P=0.01)$. A lower hazard of relapse was observed in the diploid group, but this was not significant $(\mathrm{HR}=0.62(0.33-1.18), P=0.14)$. There was a significant increasing trend in the hazard of relapse and death through increasing categories of Her-2 expression $(\mathrm{HR}=1.44(1.13-1.83)$, $P=0.003$ and $\mathrm{HR}=1.40(1.02-1.94), P=0.04$, respectively).

Predictive value of biomarkers over and above NPI Multivariate analysis shows that the effects of these cell-cycle-linked biomarkers remain statistically significant and predictive of disease-free survival even after adjusting for NPI. Ki67, $\mathrm{Mcm} 2$, geminin, Aurora A, Plk1 and H3S10ph were identified as strong independent predictors of disease-free survival over and above NPI $(\mathrm{HR}=2.13(1.08-4.23), P=0.03 ; \mathrm{HR}=2.22(1.12-4.41), P=0.02$; $\mathrm{HR}=2.64(1.27-5.49), P=0.01 ; \mathrm{HR}=2.82(1.37-5.80), P=0.005$; $\mathrm{HR}=3.31 \quad(1.57-6.97), \quad P=0.002$; and $\mathrm{HR}=2.07 \quad(1.02-4.20)$, $P=0.04$, respectively) (Figures $2 \mathrm{D}$ and 3 ). No added value was achieved by including two or more of these markers. However, there was a tendency towards Aurora A being additionally predictive over Plk1 and NPI, with an adjusted HR of 1.95 (0.90-4.23), $P=0.091$.

\section{Relationship between cell-cycle phenotype, clinicopathological variables and patient outcome}

We found that the individual cell-cycle-phase-specific biomarkers are powerful independent prognostic markers in breast cancer. This raises the question whether the cell-cycle kinetics or cell-cycle phenotype of a tumour might also have an impact on the 
A

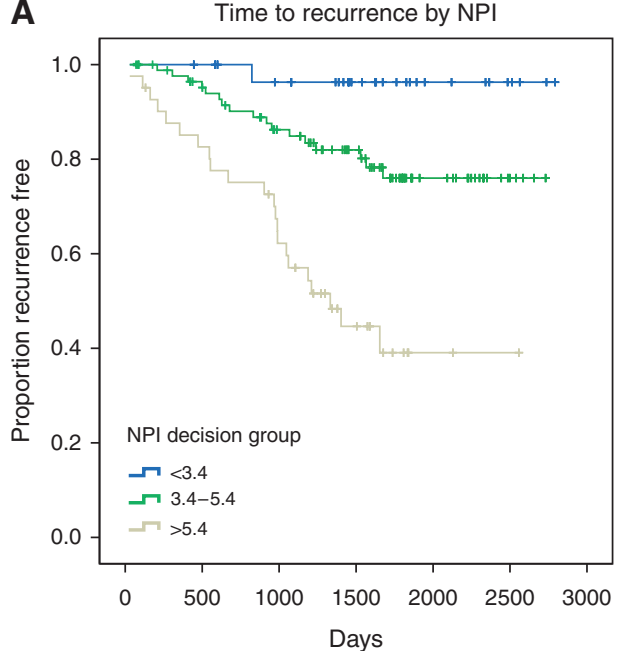

C

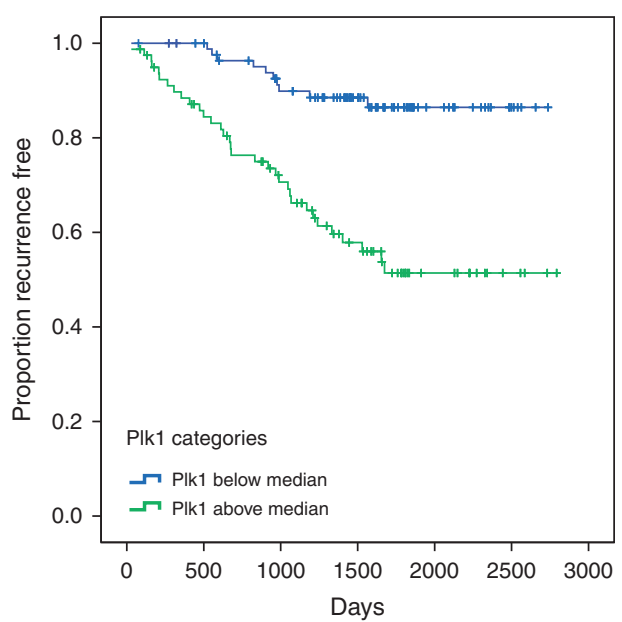

B

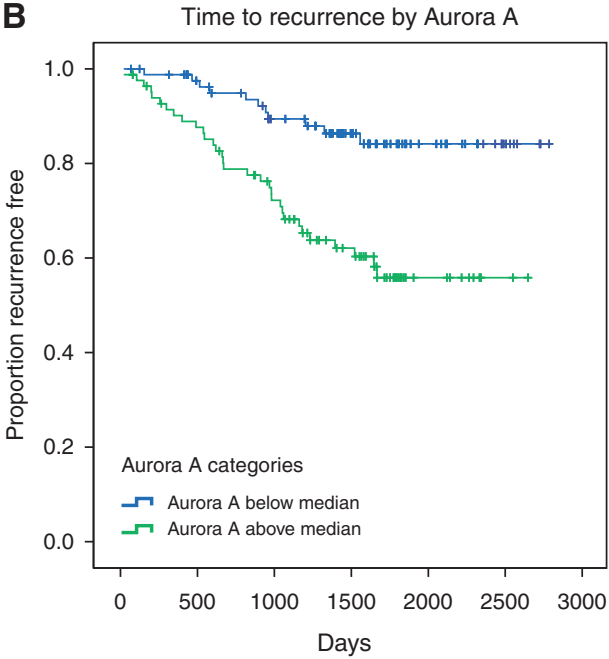

D

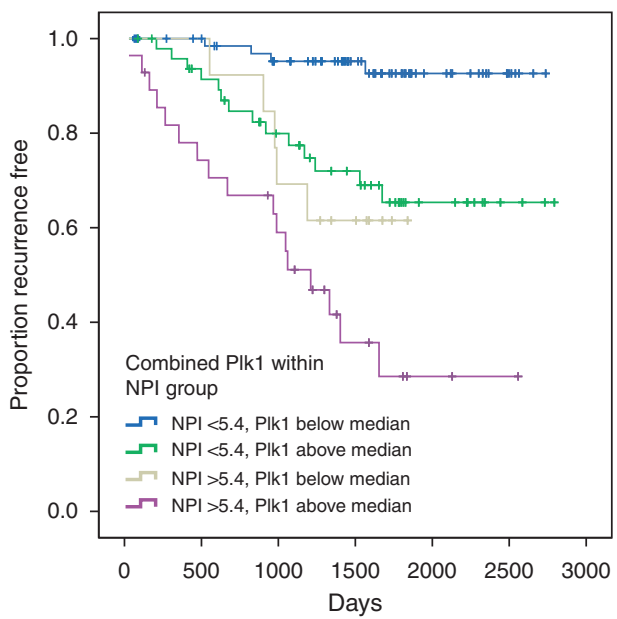

Figure 2 Kaplan-Meier curves showing association between NPI, PlkI and Aurora A and disease-free survival (days from diagnosis to death, recurrence or last follow-up) across the whole series. (A) NPI and disease-free survival segregated into the three decision group categories, $P<0.00$ I. (B) Aurora A and disease-free survival stratified by those patients lying above or below the median $\mathrm{LI} ; \mathrm{HR}=3.3 \mathrm{I}(\mathrm{I} .67-6.57), P<0.00 \mathrm{I}$. (C) PlkI and disease-free survival stratified by those patients lying above or below the median Ll; HR=4.48 (2.2I-9.09), P<0.00I. (D) Effect of PlkI after adjustment for NPI; HR=3.3I $(\mathrm{I} .57-6.97)$ risk above PlkI median relative to below median, $P=0.002$.

pathobiology of this particular tumour type. We have shown earlier in our in vitro DNA replication assays that downregulation of the Mcm2-7 licensing factors, constituents of the DNA helicase, is a ubiquitous downstream mechanism by which the proliferative capacity of cells is lowered, as cells exit the cell division cycle into quiescent (G0), differentiated or senescent out-of-cycle states (Stoeber et al, 1998, 2001; Blow and Hodgson, 2002; Kingsbury et al, 2005; Barkley et al, 2007; Williams and Stoeber, 2007). To determine the cell-cycle phenotype, we selected a cut point of $30 \%$ for $\mathrm{Mcm} 2$ protein expression to define a group $(\mathrm{Mcm} 2<30 \%$, phenotype I) in which the majority of tumour cells reside in an out-of-cycle state (Supplementary Figure 3, Figure 4). This group (phenotype I), $18 \%$ of all tumours, had geminin levels of $<7 \%$. This is in keeping with our observations in in vitro assays and selfrenewing tissues that geminin is also tightly downregulated as cells enter quiescent (G0) and differentiated out-of-cycle states (Eward et al, 2004; Kingsbury et al, 2005; Barkley et al, 2007; Williams and Stoeber, 2007) (Figure 4, Table 1). In contrast, most cancers had $\mathrm{Mcm} 2$ expression levels above $30 \%(\mathrm{Mcm} 2>30 \%)$ in which a majority of tumour cells reside in an in-cycle state (Williams and Stoeber, 2007) (Supplementary Figure 3, Figure 4, Table 1). Overall $58 \%$ of these tumours (phenotype III) displayed an active cell-cycle progression indicated by geminin levels above $7 \%$, a cut point defined by the LI for the out-of-cycle state (Figure 4, Table 1). It is of note that a large number of breast cancers (phenotype II), $24 \%$ of all tumours, displayed an in-cycle phenotype $(\mathrm{Mcm} 2>30 \%)$ but expressing geminin levels below 7\%, indicative of a G1-delayed or -arrested state (Stoeber et al, 2001; Blow and Hodgson, 2002; Gonzalez et al, 2004; Dudderidge et al, 2005; Shetty et al, 2005; Williams and Stoeber, 2007) (Figure 4, Table 1). Importantly, the distribution of the other S-G2-M biomarkers between the three groups exactly mirrors that observed for geminin, further reinforcing segregation into three distinct cell-cycle phenotypes (Figure 4).

Next, we investigated whether the cell-cycle phenotype influences in vivo behaviour and its association with clinicopathological variables including NPI. It is of note that there was no association with age, tumour size, lymph node metastasis, ER/PR or Her-2 receptor status. However, a greater proportion of grade 3 tumours, those exhibiting arrested differentiation, displayed the actively cycling phenotype. This cell-cycle profile was also associated with a higher NPI score $(P<0.001)$ (Table 1$)$. Univariate and multivariate analyses adjusted for NPI also indicated that the cell-cycle phenotype was a strong predictor of 


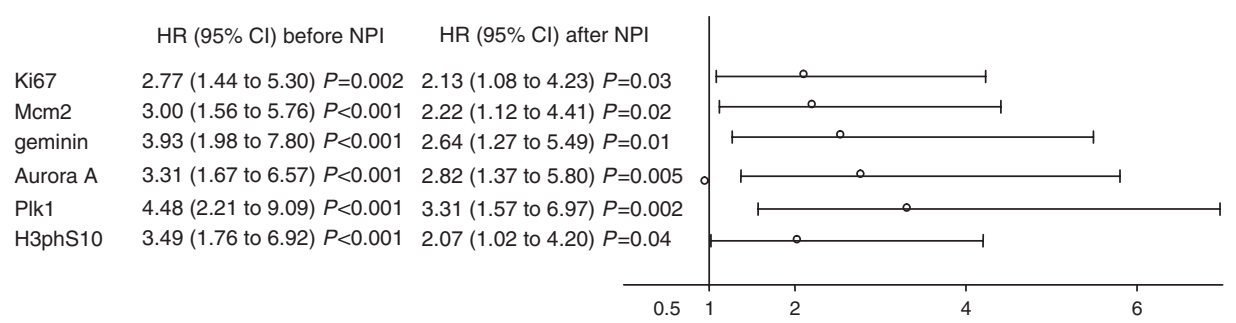

Hazard ratio $(\mathrm{HR})$ : risk of recurrence above relative to below marker median with $95 \%$ confidence interval $(\mathrm{Cl})$

Figure 3 Effect of cell-cycle biomarkers on disease-free survival before and after adjusting for NPI. All biomarkers are associated with disease-free survival. The effects remain statistically significant after adjusting for NPI, so that they are predictive, independent of NPI.
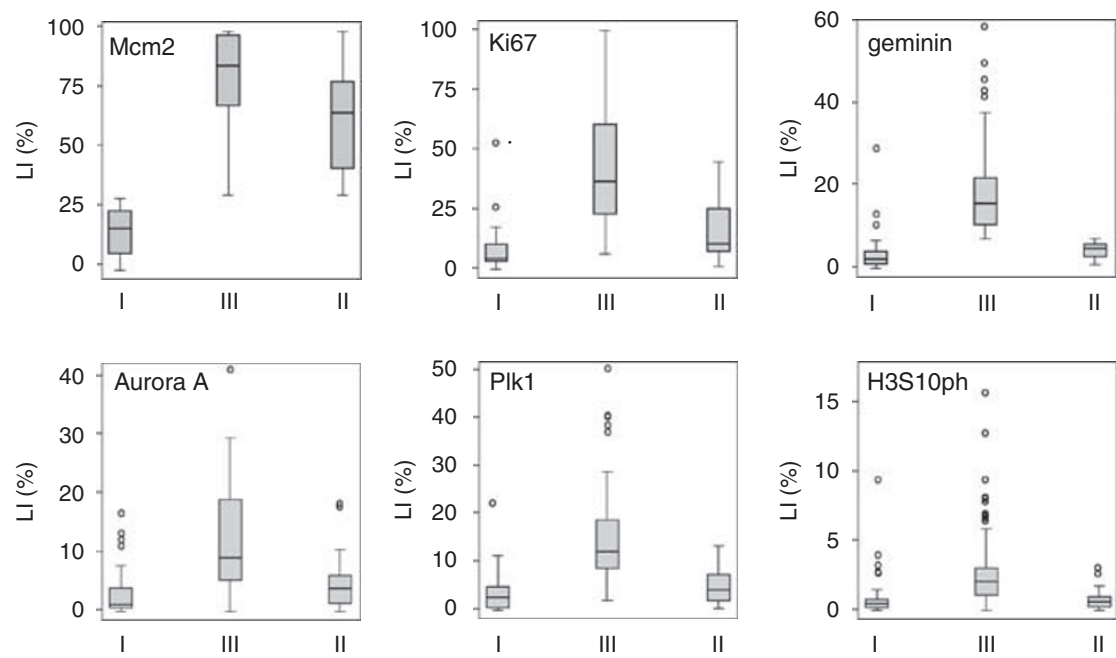

Figure 4 Distribution of cell-cycle biomarker expression defines three distinct cell-cycle phenotypes: (I) out-of-cycle state, (II) in cycle GI-delayed/ arrested state and (III) actively cycling state. The median (solid black line), interquartile range (boxed) and robust range excluding outlying cases (enclosed by lines) are shown. Outlying cases are shown by isolated points (LI, labelling index).

disease-free survival. The actively cycling phenotype (phenotype III) showed a much higher hazard of relapse than phenotypes I and II on both univariate and multivariate analyses $(\mathrm{HR}=3.90$ $(1.81-8.40), \quad P<0.001$ and $\mathrm{HR}=2.71 \quad(1.81-6.23), \quad P=0.019$, respectively) (Figure 5). Intriguingly, an almost identical low hazard of relapse was observed between well-differentiated out-ofcycle tumours and high-grade tumours exhibiting a G1-delayed/ arrested phenotype (phenotypes I and II) $(\mathrm{HR}=1.00(0.22-4.46)$, $P=0.99$; Figure 5). The actively cycling phenotype was a superior predictor of recurrence to Ki67 on univariate analysis (HR of 3.90 vs 2.77) and remained so after adjusting for Ki67 following multivariate analysis $(\mathrm{HR}=2.98(1.29-6.91), P=0.011)$, using the median value of $24 \%$ as a cut point. The actively cycling phenotype also remained a powerful predictor of recurrence on multivariate analysis even after adjusting for $\mathrm{Ki} 67$ at a $15 \%$ threshold $(\mathrm{HR}=2.80(1.16-6.78), P=0.023)$, a lower cut point that some studies have identified as an optimal cutoff value for Ki67 prognostication (Ahlin et al, 2007; De Azambuja et al, 2007). On the contrary, multivariate analysis showed that Ki67 was not significantly predictive of disease recurrence over and above the actively cycling phenotype at either the 24 or $15 \%$ cut points ( $P=0.13$ and $P=0.19$, respectively). It is of note that a strong and significant association was observed between breast cancer subtype and cell-cycle phenotype $(P<0.001)$. The proportion of patients with an actively cycling phenotype (phenotype III) was significantly higher in both the Her-2 $(91 \%, 10$ out of 11) $(P=0.003)$ and triple negative subtypes $(96 \%, 25$ out of 26$)$ $(P<0.001)$ than in the luminal subtype $(49 \%, 71$ out of 145$)$
(Figure 6). Although the proportion of hormone receptor-negative tumours displaying the out-of-cycle phenotype (phenotype I) and the G1-delayed/arrested phenotype (phenotype II) was only $4 \%$ ( 1 out of 26 ) and $9 \%$ (1 out of 11), respectively, in the luminal subtype, the proportion was $51 \%$ (74 out of 145 ), of which $21 \%$ (30 out of 145) displayed phenotype I and 30\% (44 out of 145) phenotype II (Figure 6).

\section{DISCUSSION}

Multiparameter analysis of core constituents of the cell-cycle machinery that regulate the $\mathrm{G} 1-\mathrm{S}$ and $\mathrm{G} 2-\mathrm{M}$ transitions provides a unique and detailed picture of the cell-cycle state of dynamic tumour cell populations in vivo. We selected breast cancer as a tumour model system in the first instance to test our novel cellcycle algorithm because of the urgent demand for new prognostic and predictive markers in this tumour type. Given the rising cost of health care, as well as the recognition of both an individual's genetic variation and the significant biological heterogeneity of this disease, further improvements in adjuvant treatment will inevitably require individualised therapeutic decisions. The best prognostic tool described to date for identifying which patients are most likely to benefit from adjuvant chemotherapy is the NPI. More recent analysis of additional factors, such as oestrogen, progesterone and HER2/NEU receptor status, has only marginally improved prognostic assessment (Subramaniam and Isaacs, 2005), and data emerging from global gene expression profiling, although 
Table I Relationship between cell-cycle phenotype and clinicopathological parameters

\begin{tabular}{|c|c|c|c|}
\hline & I (out-of-cycle) & II (in-cycle GI-delayed/arrested) & III (actively cycling) \\
\hline & $N=33(18 \%)$ & $N=44(24 \%)$ & $N=105(58 \%)$ \\
\hline Age, mean (s.d.) $(P=0.13)$ & $61.9(12.4)$ & $61.2(14.1)$ & $57.4(13.9)$ \\
\hline \multicolumn{4}{|l|}{ Grade $(P<0.001) *$} \\
\hline । & $27 \%(9 / 33)$ & $23 \%(10 / 44)$ & $5 \%(5 / 105)$ \\
\hline 2 & $61 \%(20 / 33)$ & $64 \%(28 / 44)$ & $30 \%(32 / 105)$ \\
\hline 3 & $12 \%(4 / 33)$ & $14 \%(6 / 44)$ & $65 \%(68 / 105)$ \\
\hline Size, mean (s.d.) $(P=0.55)$ & $24.7(17.5)$ & $29.1(19.8)$ & $28.0(17.4)$ \\
\hline Positive nodes $(P=0.23)$ & $39 \%(|2 / 3|)$ & $33 \%(13 / 40)$ & $48 \%(47 / 98)$ \\
\hline \multicolumn{4}{|l|}{ Her-2 } \\
\hline 0 & $66.7 \%(22 / 33)$ & $68.2 \%(30 / 44)$ & $53.3 \%(56 / / 05)$ \\
\hline $1+$ & $15.2 \%(5 / 33)$ & $18 \%(8 / 44)$ & $19 \%(20 / 105)$ \\
\hline $2+$ & $9.1 \%(3 / 33)$ & $4.5 \%(2 / 44)$ & $7.6 \%(8 / 105)$ \\
\hline $3+(P=0.45)$ & $9.1 \%(3 / 33)$ & $9.1 \%(4 / 44)$ & $20 \%(21 / 105)$ \\
\hline
\end{tabular}

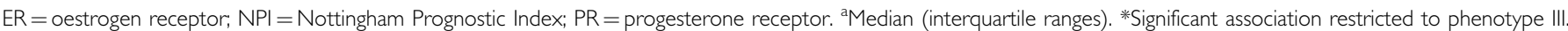

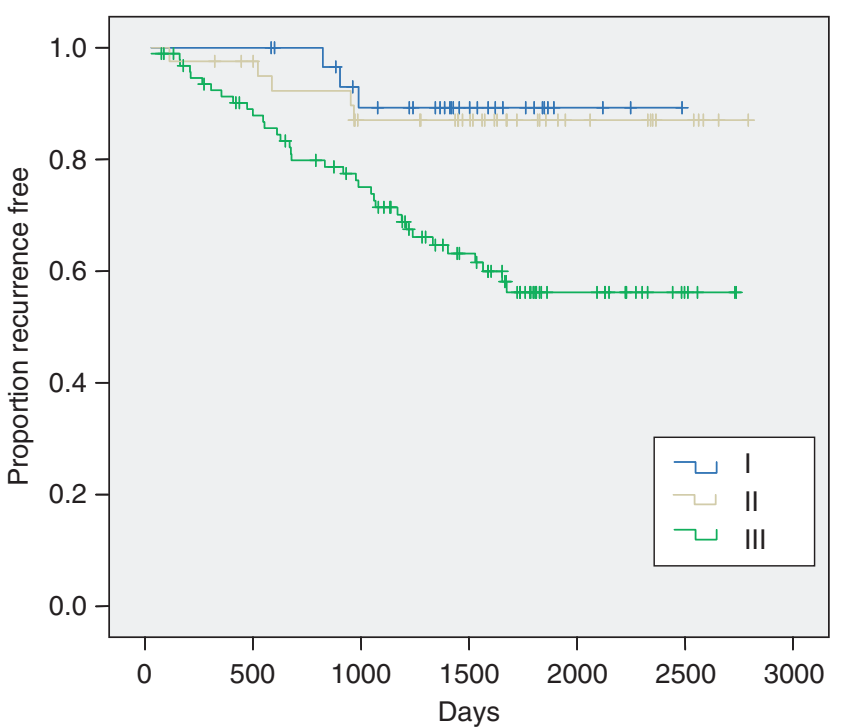

Figure 5 Kaplan-Meier curves showing association between cell-cycle phenotype and disease-free survival. (I) Out-of-cycle state, (II) in cycle GIdelayed/arrested state and (III) actively cycling state. On univariate analysis, comparing phenotype III with phenotypes I and II combined, $\mathrm{HR}=3.90$ $(|.8|-8.40), \quad P<0.001$. On multivariate analysis, adjusted for $\mathrm{NPI}$, $H R=2.7 \mid(1.18-6.23), P=0.019$.

initially encouraging (Perou et al, 1999; Van 't Veer et al, 2002), have not provided a significantly improved prognostic assessment to date (Michiels et al, 2005, 2007; Dunkler et al, 2007). Therefore, there is an urgent requirement to identify new biomarkers, which can identify those patients at most risk of relapse and who are therefore most likely to benefit from toxic chemotherapeutic interventions.
Application of our novel cell-cycle algorithm to breast cancer has revealed major insights into the cell-cycle kinetics of this disease. Arrested differentiation and increasing genomic instability, hallmarks of more aggressive tumours, was associated with increasing levels of both $\mathrm{G} 1-\mathrm{S}$ and $\mathrm{G} 2-\mathrm{M}$ biomarker expressions, indicative of an increased engagement of tumour cells in the mitotic cell division cycle. These cell-cycle biomarkers were all identified as strong independent prognostic markers over and above the prognostic value of the NPI score alone. It is of note that the $\mathrm{S}-\mathrm{G} 2-\mathrm{M}$ progression markers, Aurora A and Plk1, were identified as particularly powerful independent prognostic markers, in keeping with their higher expression levels in actively cycling tumour cell populations (Kulkarni et al, 2007; Williams and Stoeber, 2007). Importantly, our analysis revealed that breast cancer can be sub-grouped into three unique cell-cycle phenotypes, which impact on the pathobiology of these tumours. The actively cycling phenotype had a significantly higher risk of relapse when compared with out-of-cycle and G1-delayed/arrested phenotypes. The cell-cycle phenotype was also found to markedly outperform Ki67 as a predictor of recurrence in this tumour series. The cell-cycle phenotype was not associated with age, tumour size, loco-regional metastasis, ER/PR or Her-2 status. However, the actively cycling phenotype was linked to a higher NPI score because of the greater proportion of grade 3 tumours in this subgroup. The strong association between tumour grade and S-G2-M cell-cycle-phase progression mirrors the results of recent gene expression profiling studies applied to histological grade using a bottom-up supervised approach (Sotiriou et al, 2006; Sotiriou and Piccart, 2007). A gene-expression signature of 97 unique genes was identified allowing patients to be reclassified into two groups with high and low risk of recurrence. It is of note that grade 3 tumours displayed a gene expression profile significantly enriched with genes associated with cell-cycle progression and proliferation (Sotiriou et al, 2006).

There was a highly significant association between breast cancer subtype and cell-cycle phenotype. The aggressive cell-cycle 

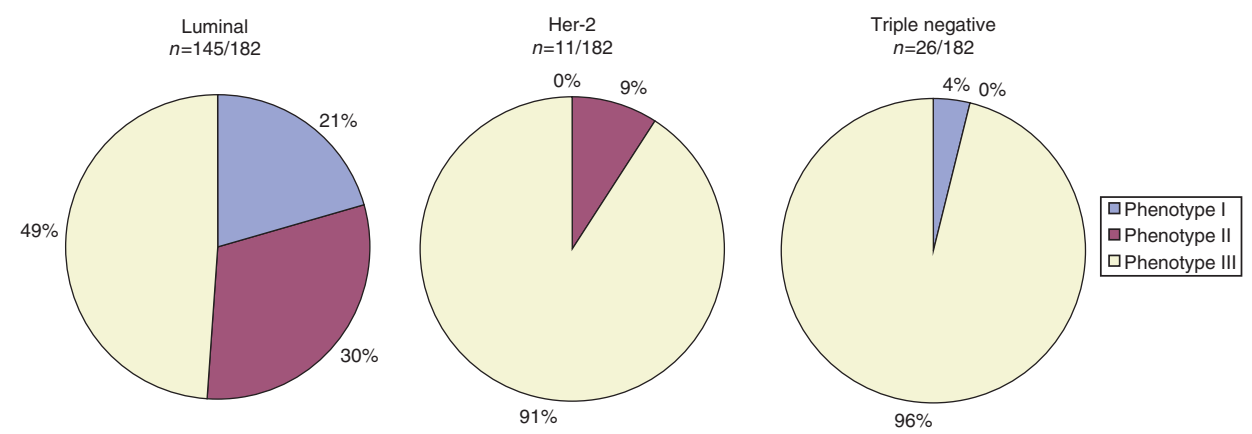

Figure 6 Relationship between cell-cycle phenotype and breast cancer subtypes. The panels show the proportion of each breast cancer subtype, which display cell-cycle phenotypes I (out of cycle), II (GI-delayed/arrested) and III (actively cycling). It is of note that the majority of Her-2 and triple negative tumours display the actively cycling phenotype (III).

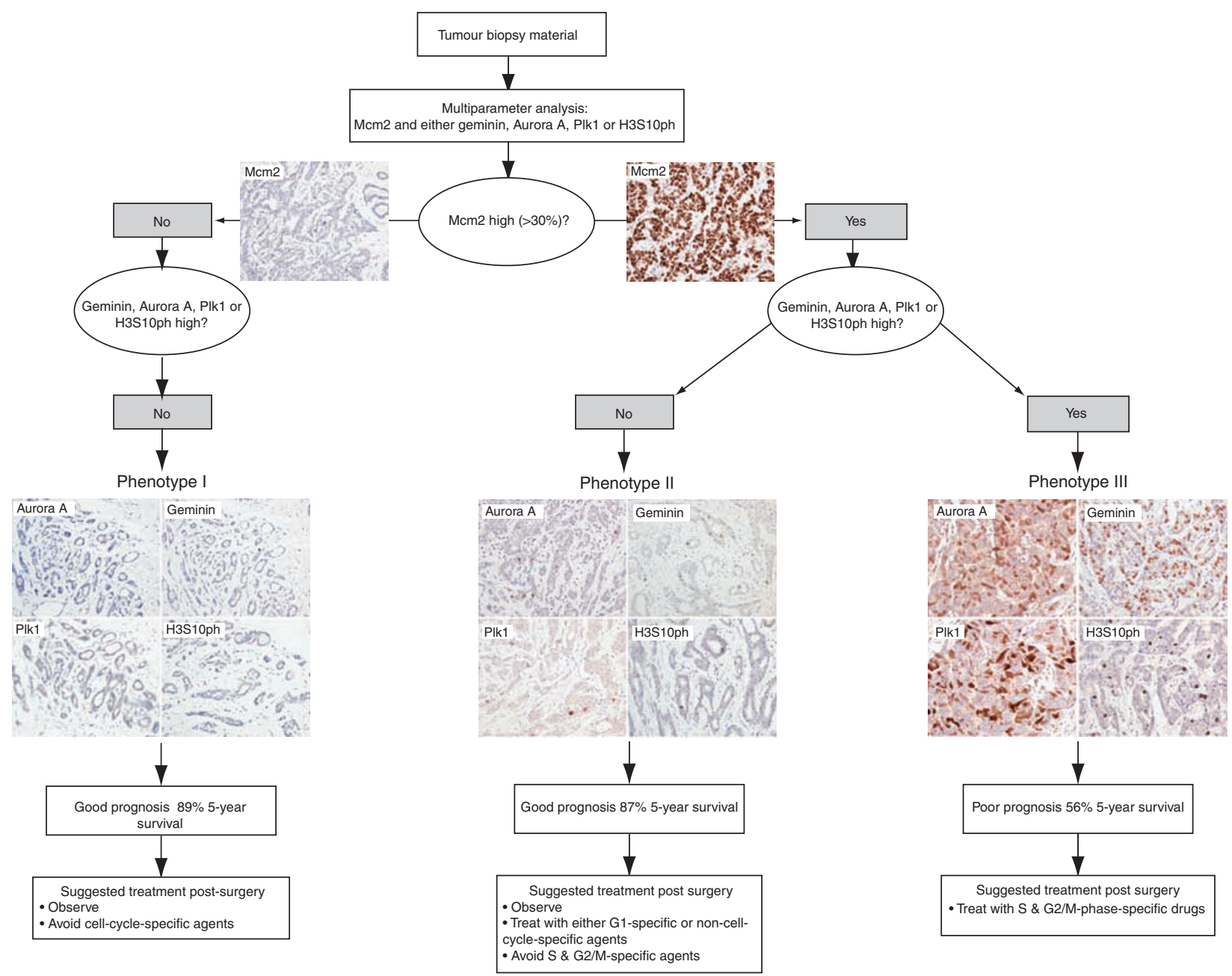

Figure 7 Proposed prognostic and predictive cell-cycle-phase algorithm in breast cancer. Three distinct cell-cycle phenotypes characterised by the differential expression of cell-cycle biomarkers Mcm2, Aurora A, geminin, PlkI and H3SIOph. Prognosis and treatment response can be predicted from the distinct immunoexpression profile displayed by each tumour.

phenotype III (actively cycling), strongly linked to a poor prognosis in our patient cohort, was much more highly represented in Her-2 subtype and triple negative tumours (hormone receptor-negative breast cancer) when compared with breast cancers of the luminal subtype. Deregulated cell-cycle control and active cell-cycle progression, therefore, appear to underlie the aggressive in vivo behaviour of these hormone receptor-negative poor prognostic subtypes. The cell-cycle phenotype, therefore, appears to represent a novel and unique independent parameter in breast cancer and is of major prognostic significance.

Interestingly, the normal mammary epithelium mimics the G1-delayed/arrested phenotype observed in breast cancer. Although the growth fraction identified by the standard proliferation marker Ki67 is small, a large number of mammary epithelial cells within the TDLU express $\mathrm{Mcm} 2$, indicating that a large number of cells appear to be replication licensed and therefore 
in-cycle (Stoeber et al, 2001; Blow and Hodgson, 2002; Shetty et al, 2005; Williams and Stoeber, 2007). However, these cells fail to express markers of cell-cycle progression, including the S-G2-M markers, geminin, Aurora A and Plk1, and the mitotic marker, $\mathrm{H} 3 \mathrm{~S} 10 \mathrm{ph}$, indicating that these cells reside in a G1-prolonged or -arrested state (Williams and Stoeber, 2007). We and others have suggested earlier that this primed, licensed state in nonproliferating breast may be an evolutionary adaptation allowing for a rapid response to pregnancy, with the consequence that failure to downregulate the DNA replication licensing pathway may increase the risk of transition to uncontrolled cellular proliferation (Stoeber et al, 2001; Blow and Hodgson, 2002). It is noteworthy in this context that a recent study exploiting a hypomorphic viable allele of $\mathrm{Mcm} 4$ was found to cause chromosomal instability and mammary adenocarcinomas in mice (Shima et al, 2007).

In addition to the strong prognostic significance of our biomarker algorithm, cell-cycle profiling of tumours has potential as a predictor of therapeutic response to cell-cycle-phase-specific agents (Figure 7). It is becoming increasingly apparent from disappointing intent-to-treat analyses of large conventionally designed trials, such as TACT (Ellis et al, 2007) and tAnGo (Poole et al, 2008) that further improvements in adjuvant treatment will inevitably require individualised therapeutic decisions. If there is a test to predict resistance to a drug or to target the patient selection for a clinical trial, the risk of clinical failure declines considerably. On the basis of our study, we hypothesise that the panel of cellcycle-regulated biomarkers discussed here may allow the prediction of treatment response to cell-cycle-phase-specific chemotherapeutic agents, including small-molecule inhibitors targeting the cell-cycle machinery (Figure 1C). It appears from our data that a proportion of patients with high-grade breast cancer receiving adjuvant chemotherapy may not gain significant benefit from present drug regimes. An almost identical low hazard of relapse was observed between patients with well-differentiated out-ofcycle tumours who are often spared chemotherapy and those with high-grade tumours exhibiting a G1-delayed/arrested phenotype. Patients with high-grade tumours, but falling into the G1-delayed/ arrested phenotype group, representing $24 \%$ of patients, are perhaps less likely to benefit from $S$ and $M$ cell-cycle-phasetargeted agents and can, therefore, be spared these toxic therapies. These patients are more likely to benefit from G1-phase-targeted agents or non-cell-cycle-specific anticancer drugs. Moreover, it is only patients showing the actively cycling, aggressive cell-cycle phenotype, and that are transiting S-G2-M phase, those are likely to benefit from conventional S- or M-phase-directed agents or from the new generation of Aurora and Plk1 mitotic kinase inhibitors that are now entering clinical trials (Keen and Taylor, 2004; Plyte and Musacchio, 2007). This is in keeping with our observations that the aggressive cell-cycle phenotype III (actively cycling) was strongly associated with Her-2 and triple negative subtypes, and it is these tumours that are characterised by high neoadjuvant response rates (Carey et al, 2007). Interestingly, in our patient cohort, $29 \%$ of patients with phenotype I, $20 \%$ of patients with phenotype II and $54 \%$ of patients with phenotype III tumours received cell-cycle-phase-specific agents in the adjuvant setting. If our prediction about cell-cycle phenotype and therapeutic benefit is correct, this would suggest that 18 out of 76 patients (phenotypes I and II) have received adjuvant therapy for little gain and that 49 out of 106 patients (phenotype III) may have been undertreated, that is, would have benefited from cellcycle-phase-specific agents. Presently, there is persistent controversy about whether adjuvant chemotherapy benefits patients bearing ER-positive tumours or not (Anonymous, 2005, 2007). Interestingly, in our analysis, $49 \%$ of the hormone receptorpositive luminal subtype exhibited the actively cycling phenotype (phenotype III) (Figure 6), suggesting that many of these patients would derive benefit from cell-cycle-phase-specific chemotherapeutic agents.

Our cell-cycle-phase analysis suggests that a simple biomarker algorithm can be applied to breast cancer to improve prognostic assessment over and above NPI, and to help identify those patients who are most likely to benefit from adjuvant chemotherapy (Figure 7). Importantly, cell-cycle phenotyping is readily applicable to routinely processed surgical biopsy material in the hospital histopathology laboratory and is amenable to highthroughput screening, using automated immunostaining platforms and quantitative image analysis. This has distinct advantages over genomic array profiling, which requires specialised laboratory facilities for RNA and/or DNA preparation, microarray platforms and bioinformatics support. Moreover, fresh material is required for RNA/DNA analysis, which disrupts the surgical specimen, potentially compromising morphological diagnosis, assessment of surgical margins of excision and staging. This is a particular problem for small samples such as those obtained using core needle biopsy techniques.

In conclusion, the biomarker algorithm discussed here provides novel insights into the cell cycle state of dynamic tumour cell populations in vivo. This algorithm has enabled us to identify three unique cell-cycle phenotypes in breast cancer, a new and independent parameter in this tumour type, which is of major prognostic significance and outperforms Ki67. In particular, deregulated cell-cycle control and accelerated cell-cycle progression appears to underlie the aggressive in vivo behaviour of the hormone receptor-negative Her-2 and triple negative subtypes (Sorlie et al, 2003; Carey et al, 2007). Further studies are now in progress to test the predictive value of this algorithm, assessing response to cell-cycle-phase-specific agents in both the adjuvant and neoadjuvant settings.

\section{ACKNOWLEDGEMENTS}

We thank Joanna Franks and Caroline Richardson for providing assistance with the retrieval of archival tissue specimens and the recording of clinicopathological parameters. This work was supported by EU Sixth Framework Programme Integrated Project 'MitoCheck' (KS and GHW).

Supplementary Information accompanies the paper on British Journal of Cancer website (http://www.nature.com/bjc)

\section{REFERENCES}

Ahlin C, Aaltonen K, Amini RM, Nevanlinna H, Fjällskog ML, Blomqvist C (2007) Ki67 and cyclin A as prognostic factors in early breast cancer. What are the optimal cut-off values? Histopathology 51: 491-498

Anonymous (2005) Effects of chemotherapy and hormonal therapy for early breast cancer on recurrence and 15-year survival: an overview of the randomised trials. Lancet 365: 1687-1717
Anonymous (2007) Polychemotherapy for early breast cancer: results from the international adjuvant breast cancer chemotherapy randomized trial. J Natl Cancer Inst 99: 506-515

Barkley LR, Hong HK, Kingsbury SR, James M, Stoeber K, Williams GH (2007) Cdc6 is a rate-limiting factor for proliferative capacity during HL60 cell differentiation. Exp Cell Res 313: 3789-3799 
Blow JJ, Hodgson B (2002) Replication licensing - defining the proliferative state? Trends Cell Biol 12: $72-78$

Carey LA, Dees EC, Sawyer L, Gatti L, Moore DT, Collichio F, Ollila DW, Sartor CI, Graham ML, Perou CM (2007) The triple negative paradox: primary tumor chemosensitivity of breast cancer subtypes. Clin Cancer Res 13: $2329-2334$

Crosio C, Fimia GM, Loury R, Kimura M, Okano Y, Zhou H, Sen S, Allis CD, Sassone-Corsi P (2002) Mitotic phosphorylation of histone H3: spatiotemporal regulation by mammalian Aurora kinases. Mol Cell Biol 22: 874-885

De Azambuja E, Cardoso F, De Castro Jr G, Colozza M, Mano MS, Durbeca V, Sotiriou C, Larsimont D, Piccart-Gebhart MJ, Paesmans M (2007) $\mathrm{Ki}-67$ as prognostic marker in early breast cancer: a meta-analysis of published studies involving 12155 patients. $\mathrm{Br} J$ Cancer 96: $1504-1513$

Dudderidge TJ, Stoeber K, Loddo M, Atkinson G, Fanshawe T, Griffiths DF, Williams GH (2005) Mcm2, geminin, and KI67 define proliferative state and are prognostic markers in renal cell carcinoma. Clin Cancer Res 11: $2510-2517$

Dunkler D, Michiels S, Schemper M (2007) Gene expression profiling: does it add predictive accuracy to clinical characteristics in cancer prognosis? Eur I Cancer 43: 745-751

Early Breast Cancer Trialists' Collaborative Group (EBCTCG) (1998a) Polychemotherapy for early breast cancer: an overview of the randomised trials. Lancet 352: 930 -942

Early Breast Cancer Trialists' Collaborative Group (EBCTCG) (1998b) Tamoxifen for early breast cancer: an overview of the randomised trials. Lancet 351: 1451 - 1467

Ellis PA, Barrett-Lee PJ, Bloomfield D, Cameron DA, Hall E, Johnson L, Johnston SRD, Bliss JM (2007) Preliminary results of the UK Taxotere as Adjuvant Chemotherapy (TACT) Trial. Breast Cancer Res Treat 106 (Suppl 1): Abstract 78

Elston CW, Ellis IO (1991) Pathological prognostic factors in breast cancer. I. The value of histological grade in breast cancer: experience from a large study with long-term follow-up. Histopathology 19: $403-410$

Eward KL, Obermann EC, Shreeram S, Loddo M, Fanshawe T, Williams C, Jung HI, Prevost AT, Blow JJ, Stoeber K, Williams GH (2004) DNA replication licensing in somatic and germ cells. J Cell Sci 117: $5875-5886$

Freeman A, Morris LS, Mills AD, Stoeber K, Laskey RA, Williams GH, Coleman N (1999) Minichromosome maintenance proteins as biological markers of dysplasia and malignancy. Clin Cancer Res 5: $2121-2132$

Gonzalez MA, Tachibana KE, Chin SF, Callagy G, Madine MA, Vowler SL, Pinder SE, Laskey RA, Coleman N (2004) Geminin predicts adverse clinical outcome in breast cancer by reflecting cell-cycle progression. J Pathol 204: $121-130$

Gonzalez MA, Tachibana KE, Laskey RA, Coleman N (2005) Control of DNA replication and its potential clinical exploitation. Nat Rev Cancer 5: $135-141$

Gown AM (2008) Current issues in ER and HER2 testing by IHC in breast cancer. Mod Pathol 21(Suppl 2): S8-S15

Gurley LR, D'Anna JA, Barham SS, Deaven LL, Tobey RA (1978) Histone phosphorylation and chromatin structure during mitosis in Chinese hamster cells. Eur J Biochem 84: 1 - 15

Haroske G, Giroud F, Reith A, Bocking A (1998) 1997 ESACP consensus report on diagnostic DNA image cytometry. Part I: basic considerations and recommendations for preparation, measurement and interpretation. European Society for Analytical Cellular Pathology. Anal Cell Pathol 17: $189-200$

Harvey JM, Clark GM, Osborne CK, Allred DC (1999) Estrogen receptor status by immunohistochemistry is superior to the ligand-binding assay for predicting response to adjuvant endocrine therapy in breast cancer. $J$ Clin Oncol 17: 1474-1481

Hook SS, Lin JJ, Dutta A (2007) Mechanisms to control rereplication and implications for cancer. Curr Opin Cell Biol 19: 663-671

Keen N, Taylor S (2004) Aurora-kinase inhibitors as anticancer agents. Nat Rev Cancer 4: $927-936$

Kingsbury SR, Loddo M, Fanshawe T, Obermann EC, Prevost AT, Stoeber $\mathrm{K}$, Williams GH (2005) Repression of DNA replication licensing in quiescence is independent of geminin and may define the cell cycle state of progenitor cells. Exp Cell Res 309: 56-67

Kulkarni AA, Loddo M, Leo E, Rashid M, Eward KL, Fanshawe TR, Butcher J, Frost A, Ledermann JA, Williams GH, Stoeber K (2007) DNA replication licensing factors and aurora kinases are linked to aneuploidy and clinical outcome in epithelial ovarian carcinoma. Clin Cancer Res 13: $6153-6161$

Machida YJ, Hamlin JL, Dutta A (2005) Right place, right time, and only once: replication initiation in metazoans. Cell 123: 13-24

Michiels S, Koscielny S, Hill C (2005) Prediction of cancer outcome with microarrays: a multiple random validation strategy. Lancet 365: $488-492$

Michiels S, Koscielny S, Hill C (2007) Interpretation of microarray data in cancer. Br J Cancer 96: 1155-1158

Nigg EA (2001) Mitotic kinases as regulators of cell division and its checkpoints. Nat Rev Mol Cell Biol 2: 21-32

Obermann EC, Eward KL, Dogan A, Paul EA, Loddo M, Munson P, Williams GH, Stoeber K (2005) DNA replication licensing in peripheral B-cell lymphoma. J Pathol 205: 318-328

Paik S, Shak S, Tang G, Kim C, Baker J, Cronin M, Baehner FL, Walker MG, Watson D, Park T, Hiller W, Fisher ER, Wickerham DL, Bryant J, Wolmark N (2004) A multigene assay to predict recurrence of tamoxifen-treated, node-negative breast cancer. $N$ Engl J Med 351: $2817-2826$

Paulson JR, Taylor SS (1982) Phosphorylation of histones 1 and 3 and nonhistone high mobility group 14 by an endogenous kinase in $\mathrm{HeLa}$ metaphase chromosomes. J Biol Chem 257: 6064-6072

Perou CM, Jeffrey SS, van de RM, Rees CA, Eisen MB, Ross DT, Pergamenschikov A, Williams CF, Zhu SX, Lee JC, Lashkari D, Shalon D, Brown PO, Botstein D (1999) Distinctive gene expression patterns in human mammary epithelial cells and breast cancers. Proc Natl Acad Sci USA 96: $9212-9217$

Planas-Silva MD, Weinberg RA (1997) The restriction point and control of cell proliferation. Curr Opin Cell Biol 9: 768-772

Plyte S, Musacchio A (2007) PLK1 inhibitors: setting the mitotic death trap. Curr Biol 17: R280 - R283

Poole CJ, Hiller L, Howard HC, Dunn JA, Canney P, Wardley AM, Kennedy MJ, Coleman RE, Leonard RC, Earl HM, tAnGo trial collaborators (2008) tAnGo: a randomized phase III trial of gemcitabine (gem) in paclitaxel-containing, epirubicin/cyclophosphamide-based, adjuvant chemotherapy (CT) for women with early-stage breast cancer (EBC). J Clin Oncol 26 (Suppl 1): Abstract 506

Rampaul RS, Pinder SE, Elston CW, Ellis IO (2001) Prognostic and predictive factors in primary breast cancer and their role in patient management: The Nottingham Breast Team. Eur J Surg Oncol 27: $229-238$

Ross DT, Scherf U, Eisen MB, Perou CM, Rees C, Spellman P, Iyer V, Jeffrey SS, van de RM, Waltham M, Pergamenschikov A, Lee JC, Lashkari D, Shalon D, Myers TG, Weinstein JN, Botstein D, Brown PO (2000) Systematic variation in gene expression patterns in human cancer cell lines. Nat Genet 24: 227-235

Sherr CJ, Roberts JM (2004) Living with or without cyclins and cyclindependent kinases. Genes Dev 18: 2699-2711

Shetty A, Loddo M, Fanshawe T, Prevost AT, Sainsbury R, Williams GH, Stoeber K (2005) DNA replication licensing and cell cycle kinetics of normal and neoplastic breast. Br J Cancer 93: 1295-1300

Shima N, Alcaraz A, Liachko I, Buske TR, Andrews CA, Munroe RJ, Hartford SA, Tye BK, Schimenti JC (2007) A viable allele of Mcm4 causes chromosome instability and mammary adenocarcinomas in mice. Nat Genet 39: $93-98$

Sorlie T, Perou CM, Tibshirani R, Aas T, Geisler S, Johnsen H, Hastie T, Eisen MB, van de RM, Jeffrey SS, Thorsen T, Quist $H$, Matese JC, Brown PO, Botstein D, Eystein LP, Borresen-Dale AL (2001) Gene expression patterns of breast carcinomas distinguish tumor subclasses with clinical implications. Proc Natl Acad Sci USA 98: $10869-10874$

Sorlie T, Tibshirani R, Parker J, Hastie T, Marron JS, Nobel A, Deng S, Johnsen H, Pesich R, Geisler S, Demeter J, Perou CM, Lonning PE, Brown PO, Borresen-Dale AL, Botstein D (2003) Repeated observation of breast tumor subtypes in independent gene expression data sets. Proc Natl Acad Sci USA 100: 8418-8423

Sotiriou C, Piccart MJ (2007) Taking gene-expression profiling to the clinic: when will molecular signatures become relevant to patient care? Nat Rev Cancer 7: 545-553

Sotiriou C, Wirapati P, Loi S, Harris A, Fox S, Smeds J, Nordgren H, Farmer P, Praz V, Haibe-Kains B, Desmedt C, Larsimont D, Cardoso F, Peterse H, Nuyten D, Buyse M, Van de Vijver MJ, Bergh J, Piccart M, Delorenzi M (2006) Gene expression profiling in breast cancer: understanding the molecular basis of histologic grade to improve prognosis. J Natl Cancer Inst 98: $262-272$ 
Cell cycle biomarkers in breast cancer

M Loddo et al

Stoeber K, Mills AD, Kubota Y, Krude T, Romanowski P, Marheineke K, Laskey RA, Williams GH (1998) Cdc6 protein causes premature entry into $S$ phase in a mammalian cell-free system. EMBO J 17: 7219-7229

Stoeber K, Tlsty TD, Happerfield L, Thomas GA, Romanov S, Bobrow L, Williams ED, Williams GH (2001) DNA replication licensing and human cell proliferation. J Cell Sci 114: 2027-2041

Subramaniam DS, Isaacs C (2005) Utilizing prognostic and predictive factors in breast cancer. Curr Treat Options Oncol 6: 147-159

Tachibana KE, Gonzalez MA, Coleman N (2005) Cell-cycle-dependent regulation of DNA replication and its relevance to cancer pathology. J Pathol 205: 123-129

Van 't Veer LJ, Dai H, van de Vijver MJ, He YD, Hart AA, Mao M, Peterse HL, van der KK, Marton MJ, Witteveen AT, Schreiber GJ, Kerkhoven RM, Roberts C, Linsley PS, Bernards R, Friend SH (2002) Gene expression profiling predicts clinical outcome of breast cancer. Nature 415: $530-536$
Wei Y, Yu L, Bowen J, Gorovsky MA, Allis CD (1999) Phosphorylation of histone $\mathrm{H} 3$ is required for proper chromosome condensation and segregation. Cell 97: 99-109

Wharton SB, Hibberd S, Eward KL, Crimmins D, Jellinek DA, Levy D, Stoeber K, Williams GH (2004) DNA replication licensing and cell cycle kinetics of oligodendroglial tumours. Br J Cancer 91: 262-269

Whitfield ML, George LK, Grant GD, Perou CM (2006) Common markers of proliferation. Nat Rev Cancer 6: 99-106

Williams GH, Stoeber K (2007) Cell cycle markers in clinical oncology. Curr Opin Cell Biol 19: 672-679

Wohlschlegel JA, Kutok JL, Weng AP, Dutta A (2002) Expression of geminin as a marker of cell proliferation in normal tissues and malignancies. Am J Pathol 161: 267-273

Zetterberg A, Larsson O (1985) Kinetic analysis of regulatory events in G1 leading to proliferation or quiescence of Swiss 3T3 cells. Proc Natl Acad Sci USA 82: $5365-5369$ 